\title{
ON SOME NEW AND OLD MOLLUSCAN GENERIC NAMES.
}

\author{
By T'om Iredale.
}

\author{
Read 12th November, 1915.
}

Tне names here dealt with are such as have attracted special attention while determining Mollusca from Lord Howe Island in connexion with Kermadec and Norfolk Island forms. Complications have ensued so that it seems convenient to expound some of my solutions herewith. I am very gratified at the continuation of the criticism, in correspondence as well as in print, of my previous notes by Dr. Dall, M. Cossmann, and Mr. Hedley. It is my custom to acknowledge the work of such, and I would here record the fact that a paper by Dr. Dall on the "Orthaulax pugnax Zone", published "Jan. 21, 1915 ", was not received in England, owing to the unusual conditions existing, until the first week in September, 1915. Consequently notes written and published by me long after the first date do not mention this paper, while I was dealing with names that occurred in it. The points wherein my conclusions differ from those arrived at by Dr. Dall will be considered later. It is necessary to make this apology, since all systematic malacologists are so deeply indebted to Dr. Dall's writings, whether his conclusions be absolutely accepted or otherwise. I have received one criticism of my previous notes in which the advice was tendered to "go slow" and lessen the risk of proposing synonyms. I might remark that in cases such as are hereafter set out it is quite impossible to do otherwise than "go slow", though, in the present chaotic state of classification, that does not obviate the chance of creating unacceptable names. It is only by the co-operation of other workers, through the publication of incomplete notes, that the truth can be arrived at in very complex cases.

\section{Anarithya, nov. gen.}

From a dredging made by Mr. Roy Bell in 15-20 fath. off Lord Howe Island I sorted out some half-dozen shells whose beauty greatly pleased me: my tentative attachment was "Columbella sensu latissimo", with distinct leanings towards the Turridæ. Mr. Edgar A. Smith generously helped me in the same manner as when dealing with many other shells, and I now record the results of our search. It was found that owing to its peculiarities the shell had received (at least) six specific names, three writers assigning it to Columbella, one to Cythara, one to Mitra, and one to Clavatula. Following up its history I found it had been placed, at various times, under no less than thirteen genera or sub-genera. It correlates with no known genus at all well, hence I allot it one for itself. Before taking this action, many generic names had to be considered, and I give notes on these to receive criticism.

It had better first be stated that the genus name is proposed for the shell commonly known as "Columbella lachryma, Gaskoin", 
which I consider conspecific with Clavatula metula, Hinds, and my conclusions will be quickly followed by the synonymy here given :-

Anarithia metula (Hinds).

Clavatula metula, Hinds, Proc. Zool. Soc., Oct. 1843, p. 44. Ex Mus. Belcher. Hab.-(?). Zool. Voy. Sulphur, pl. vii, tig. 12.

Mitra lachryma, Reeve, Conch. Icon., Mitra, sp. 258, fig. 258, March, 1845. Ex Mus. Metcalfe. Hab.-(?)

$C[$ olombella $]$ pamila, Chenu, Illust. Conch., pl. xxii, 1848. Hab.-(?)

Columbella lachryma, Reeve, Conch. Icon., Columbi sp. 125, fig. 125,

Nov. 1851. Ex Gaskoin MS. In Mus. Cuming. Hab.-(?)

Cythara garrettii, Pease, Proc. Zool. Soc., 1860, p. 147. In Mus.

Cuming. Sandwich Islands.

Columbella pusiola, Schmeltz, Mus. Godeff. Cat., iv, p. 88, May, 1869, nomen nudum. Fiji, Samoa. (Anachis) pusiola, Dunker, Malak. Blatt., vol. xviii, p. 157, 1871. Fiji.

Columbella lachryma, Hervier, Journ. de Conch., vol. xlvii, Dec. 26, 1899 , p. 380 ; Lifu. Var. $a$, producta, p. 381 ; Lifu. Var. $\beta$, abbreviata, p. 381 ; Lifu. Var. $\gamma$, nitescens, p. 382 ; Lifu.

Columbella sublachryma, id., p. 382, pl. xiv, fig. 1; Lifu. Var. a, spharica, p. 384 ; Lifu.

The wanderings of the names from genus to genus may be recorded individually in chronological order.

Since Hind's metula was described from a private museum, it was probably inaccessible to most workers. Hence Reeve copied Hind's figure, but placed it in his genus Pleurotoma, sp. 238, Nov. 1845, not recognizing it as his Mitra lachryma just previously figured. 'Tryon, again, copied Reeve's figure when he placed it in Mangilia (Man. Conch., vol. vi, 1884, p. 269, pl. xvi, fig. 59), the figure gaining no accuracy in the process. H. \& A. Adams, in the Gen. Rec. Moll., vol. i, 1853 , p. 96, placed metula in Defrancia, and Mitra lachryma, p. 178, in Turricula (Pusia). The unique type of metula was later acquired by the British Museum, and from the study of it Pace (Proc. Malac. Soc., vol. v, 1902, p. 106, April) classed it with the Columbellidæ, but without any note as to its identity. I believe this is the first time it has been recognized as conspecific with "lachryma". As indicated above, Reeve described a Mitra and later a Columbella under the same specific name "lachryma". It appears probable that Gaskoin, to whom the latter name was accredited, had recognized the Reevean Mitra in a shell in the Cuming Collection, and Reeve was ignorant of this fact. Chenu was the first to place it in Colombella $[$ sic $]$, and of course, not concerned with Clavatula and Mitra, gave it a new specific name "pamila". Pease, ignorant of the preceding history, called it Cythara garrettii when he procured it at the Sandwich Islands, this being the first locality ascertained.

Carpenter, in the Proc. Zool. Soc., 1865, p. 516, wrote a note upon Pease's manuscript(?) names, observing " $C[$ ithara $]$ garrettii is a Mitrella". I have great respect for the accuracy displayed by Carpenter, and cannot understand how he should have blundered so badly in this instance, since Pease's names had been published in the 
same journal in 1860. Dunker described Anachis pusiola, comparing it with $C$. garrettii, Pease, and almost immediately afterwards Schmeltz (Mus. Godeff. Cat., v, Feb. 1874, p. 127) synonymized both C. pusiola, Dkr., and C.garrettii, Pse., with Columbella lacryma [sic], Gaskoin. Hervier made a detailed study of this shell and its relations, writing: “Elle paraît être le type d'un petit groupe intéressant, caractérisé par son galbe spécial, son mode de sculpture, et la conformation de son ouverture." $\mathrm{He}$ describes three varieties: of "abbreviata" he notes, "Cette forme serait-elle le $C$. pusiola, Dunker, ou même le $C$.linigera, Duclos? Je n'ai pu m'en convaincre" ; and of "nitescens," "Cette forme correspond-elle au C. gracilis, Reeve, des îles Fidji, qui parait décrite et figurée sur un échantillon jeuné ?" He then added a species C. sublachryma, with a variety sphcerica.

I have studied the figure of $C$ [olombella $]$ linigera, Chenu, Illust. Conch., 1846, pl. xvii, figs. 13-14, and would not associate it with this species, but believe it is referable to another shell also recovered from these Lord Howe 15-20 fathom dredgings, which is a true Zafra. I will elaborate this point later.

I have not found a $C$. gracilis, Reeve, and conclude Hervier referred to Citharopsis gracilis, Pease (Amer. Journ. Conch., vol. iv, Nov. 3 , 1868, p. 97, pl. xi, fig. 20: Paumotus). The figure appears to be drawn from an adult specimen which should be classed under Seminella. I would record Tryon's remark under $C$ [olumbella graciilis, Pease (Man. Conch., vol. v, 1883, p. 167): "Pretty constant in form, but varying in sculpture and coloring. Pease described it from a not perfectly adult specimen. Dunker described the adult under the name of $C$. pusiola. A portion of the original set of the latter species is before me. Mr. Garrett believed $C$. pusiola to $=C$. lachryma, Gaskoin." There is little close affinity between "C. lachryma" and "C. gracilis", so I at present cannot understand Tryon's note.

However much "lachryma" varies-and there is a considerable amount of limited variation-it is an easily recognizable shell. As Hervier noted, it is marked by a striking facies. It has, however, been referred to several groups, and these need consideration. When Pace reviewed Columbelloid names (Proc. Malac. Soc., vol. v, April, 1902) he observed much confusion in connexion with the names Citharopsis, Pease, and Seminella, Pease, and concluded, p. 42, "It will be best, in my opinion, to restrict the name Citharopsis to the very distinct group of $C$. lachryma (Rve.), which species is one of those enumerated by Pease, and Seminella to the group of $C$. troglodytes, Sow." ; and p. 44, "If C. lachryma (Rve.) is correctly referred to the Columbellidæ, Cantraine's Mitra olivoidea must accompany it . . . the columella folds are unlike those of Mitra, and resembles rather the peculiar split tooth which is met with in so many Columbellidæ." I do not conclude from this that Pace considered C. lachryma (Rve.) congeneric with Mitra olivoidea, Cantraine; the latter is the type of Mitrolumna, Bucquoy, Dollfus, \& Dautzenberg, and I would not place "lachryma" in the same genus, and in this opinion Mr. E. A. Smith agrees. It was probably due to Pace's comments that Hedley 
wrote (Proc. Linn. Soc. N.S.W., vol. xxxviii, 1913, pp. 324-5) when advocating the usage of Zafra, A. Adams: "This genus has been neglected and misunderstood. ... Here H. Adams referred a new species, Zafra pupoidea, thereby misleading Nevill, Fischer, and Tryon to transfer Zafra to the Pleurotomidæ, with $Z$. pupoidea for type. But H. Adams emphasized his own error by noting that Seminella of Pease [type Columbella garretti, Tryon] was equivalent to Zafra. Another name for 'the minute ribbed Columbellidæ occurring in the Indo-Pacific region is Citharopsis, Pease, type Columbella lachryma, Reeve (Mitra lachryma, Reeve, 1845= Columbella pamila, Chenu, 1848)'." Hedley then gave a list of Australian shells he proposed to refer to Zafra, and on p. 328 introduced a new sub-genus Retizafra, with Pyrene gemmulifera, Hedley, as type.

This necessitated the investigation of Seminella and Citharopsis. In the Amer. Journ. Conch., vol. iii, Jan. 2, 1868, p. 233, Pease wrote: "A group of small shells inhabit Polynesia, represented by Cithara ornata, Pse., varia, Pse., etc., which have been referred by Dr. Carpenter to the genus Anachis, A. Ad. Species also occur on West Coast of America and in the West Indies, which differ but slightly from the Polynesian. Perfect specimens are rarely met with. Having collected a few of each species, I find they present the following characters: Smooth, shining, colours sometimes iridescent, more or less closely ribbed longitudinally, and striated transversely; ribs continuous; aperture narrow, outer and inner lips denticulate or lyrate within, inner lip bordered by a slight callosity, outer lip sinuated at or near its junction with the body-whorl. The denticulations are often worn off, and the sinus is shallowed or entirely disappears, as the edge of the lip is sharp and thin." p. 234 : "I agree with Dr. Carpenter that they should be classed with Columbellina, but not with Anachis, A. Ad., which appears to be a conglomerate genus. C. miser, pacifica, etc., are not very closely related to the strongly-ribbed Panamic forms, nor to the small iridescent species of Polynesia. I would therefore propose that the latter should be separated under the name of Seminella."

Apparently no Cithara ornata had been described by Pease, but Cythara varia, Pease, had been published in the Proc. Zool. Soc., 1860 , p. 147. Consequently this species, by monotypy, became the type of Seminella. Carpenter, in the Proc. Zool. Soc., 1865, p. 516, observed " $C[$ ithara $]$ varia, Pse., is probably an Anachis = Columbella virginea, Gld. (from type)".

In a well-known work quoted as the "Donum Bismarckianum", 1871 , the name was changed. In the introduction it is recorded that part of this appeared as a paper by Langkavel alone in the Programm Friedrichs-Werderschen Gymnasium. I had not seen this quoted, and found it was not available in the British Museum (Natural History) Library. I indicated my want to Mr. Alexander Reynell, who is becoming famed for his craft in securing rare conchological works, and in this case he immediately procured a copy, from which, by his permission, I make the following notes. In April, 1871, there 
appeared in the Programm Friedrichs-Werderschen Gymnasium the article by Langkavel alone on a collection of South Sea shells. This article ran into 35 pages, accompanied by 4 plates with explanation. 'The first 24 pages are exactly the same as those of the better known "Donum Bismarckianum", but in the latter reprint 43 additional pages appear instead of only 11 . That is, the 35 pages of the Programm have in the "Donum " been extended to 67 . The 4 plates are the same, absolutely, but in the only copy of the Programm seen these are uncoloured, whereas they are coloured in the "Donum". All the figures therefore date from the Programm as well as the first 24 pages; the majority of the rest of the matter is, of course, novel in the "Donum". This note is here interposed because in the Programm, p. 23, Langkavel proposed the new name "Columbella (Seminella) Peasei, nobis. Cythara varia, Pease, P.Z.S., 1860, p. 147. Seminella, v., Pse., A. J. C., iii, 1867, 233, 234". This change was made on account of the prior Columbella varia, Sowerby, 1832. On the same page was recorded Columbella (Sêminella) lacrima [sic], Gaskoin, Cythara garrettii, Pse., being given as synonym. Figures of both these species appear on pl. i, figs. 17, 18, but unfortunately they are not very good. No reference to Columbella virginea, Gould, was made by Langkavel.

Tryon (Man. Conch., vol. v, 1883, p. 245) included both species in Columbella, using peasei as the specific name of the former, and, apparently ignorant of Carpenter's note, also included (p. 180) Columbella virginea, Gould, remarking that the type was probably lost. It seems that fortunately such is not the case, but, anyhow, in the British Museum there is preserved a specimen of virginea, Gould, received direct from Gould by Cuming, and therefore a paratype ; this authentic specimen agrees exactly with authentic specimens, probably types, of Pease's C. varia in the same collection. Columbella virginea was described by Gould in the Proc. Bost. Soc. Nat. Hist., vol. vii, Sept. 1860, p. 335: China seas; and a tedious search for priority is obviated by the fact that there is a prior Colombella [sic] virginea, Duclos, Monogr. Colomb., 1840, pl. ii, figs. 15, 16. At present I regard Seminella as a well-marked generic group.

A pparently further considering the matter, Pease, in the same Journal (vol. iv, pt. 3, Nov. 3, 1868, p. 97), correctly proposed "Citharopsis, nov. gen. Description. T. parva, fusiformi, longitudinaliter costata, nitida, interdum iridescente; labro superne emarginato, intus lirato aut denticulato; apertura angusta. Remarks. I establish the above genus to include a group of small, bright shining species, resembling Anachis in the character of their aperture and in being longitudinally ribbed or partially so, and Cithara in general shape and emargination of outer lip. Mr. Cuming has placed one species with the Tritons (T. pusillus, Pse.). Mr. Gaskoin attached the name of Columbella lachryma to another; Dr. Carpenter connects them with Anachis, and I have described several as Cithara. They evidently belong to the Columbellidæ". Two species were then described, Citharopsis ornata, p. 97, pl. xi, fig. 49, from Tahiti, and C. gracilis, p. 97, pl. xi, fig. 20, from the Paumotus. 
Tryon, in the Man. Conch., vol. v, 1883, p. 168, ranged the species under Columbella, renaming Citharopsis ornata, Pse., Columbella garrettii, Tryon. This name has been accepted, but it was invalid on account of Cythara garrettii, a synonym of C. lachryma, Reeve. Again, authentic specimens of Citharopsis ornata, Pse., are preserved in the British Museum, and these are absolutely true Zafra, and have even been determined as variants of troglodytes, Souverbie. Further, there is a prior Cytharopsis, A. Adams, Ann. Mag. Nat. Hist., ser. III, vol. $\mathbf{x v}$, April 1, 1865, p. 322 . C. gracilis, Pse., as noted above, I determine to be a true Seminella.

The only other species mentioned in relation with Citharopsis, viz. $T$ (riton) pusillus, Pse., may be here commented upon. This shell was described in the Proc. Zool. Soc., 1860, p. 434, as Triton pusilla from the Sandwich Islands, the type being preserved in the British Museum in the Cuming Collection. Tryon, in the Man. Conch., vol. iii, 1881, p. 31, ranged it under Triton in the sub-genus Epidromus, and on pl. xvi, tig. 156, gave a figure, observing, "Figured from a typical example in Coll. Acad. Phila." Mr. J. R. Le B. Tomlin, identifying shells received from the Sandwich Islands, showed me this species, and I immediately recognized it as one of my puzzling forms. It very rarely occurred in this Lord Howe dredging, and also rarely as a sub-littoral shell at Norfolk Island. When looking up Chenu I observed the same species as $C[$ olombella $]$ isomella, Illust. Conch., 1846, pl. ix, figs. 7-8, and Mr. Tomlin has told me he has made, independently, the same determination. It is curious to quote Tryon's remarks concerning this species (vol. v, p. 173) - "The present species may possibly be a small Pleurotomoid."

The variation displayed by this species appears to be great, as I suggest all the shells from Lifu are conspecific, though Hervier differentiated these into three species with many varieties as follows in the Journ. de Conch., vol. xlvii, 1899, p. 358, Columbella lifouana, pl. xiii, fig. 6 : Lifu. p. 359 , var. a, rufolineata, and p. 360 , var. $\beta$, intermissa. On p. 360, Columbella isomella, Duclos, with p. 361, var. a, transversa, var. $\beta$, subfelina, pl. xiii, fig. 7 , and p. 362 , var. $\gamma$, notata. On p. 362, Columbella striatula, Dunker, with p. 363, vars. a, sulphurea, $\beta$, rubicunda, $\%$, subcarnea, $\delta$, lineolata, and $\epsilon$, immaculata.

It is possible that there may be more than one species, but as my few specimens also show variation I conclude we have here a very variable species.

I propose to designate this generically by the new name:-

\section{ZaFroNa, nov. gen.}

and name Colombella [sic] isomella, Duclos, as type. I think C. burnupi, E. A. Smith (Journ. Conch., vol. x, Oct. 1, 1901, p. 112, pl. i, fig. 2: Natal), is congeneric, and I note it is there recorded "The radula is columbelloid".

I hope later to deal in detail with the species referable to the abovenamed genera, but would observe that Zafra seems easily limited, though the species vary in size, sculpture, and shape. Thus some are very small, $2 \mathrm{~mm}$., to comparatively large, $5 \mathrm{~mm}$., from slender to 
obese, and from closely sculptured to almost smooth. Hedley's beautiful figures and descriptions in the Proc. Linn. Soc. N.S.W., vol. $\mathrm{x} \times x i x$, pt. 4, 1915, pp. 740-5, pl. lxxxiii, figs. 68-72, 74, 75, 77, of typical Zafra should enable the easy recognition of this genus. I am doubtful about the inclusion of Pyrene lurida, and have written to $\mathrm{Mr}$. Hedley for his further opinion. I, however, have not the least doubt in rejecting Columbella abyssicola, Brazier, from this association. Mr. Hedley has furnished splendid illustrations of this shell in the Proc. Linn. Soc. N S.W., vol. xxxii, Oct. 25, 1907, pl. xix, figs. 40-3, and these show the generic characters of quite another group, of which I have a magnificent species in these same dredgings. Other smooth "Columbelloids" I will treat at a later opportunity, but would just summarize this note as follows :-

Genus Ana rithma, nov. gen.- Here proposed for Clavatula metula, Hinds. Hervier has added other species to this group, which I will later discuss. It must be repeated that these are preliminary notes published for the sake of criticism, and later I will develop any points indicated.

Genus Zafra, A. Adams.-Hedley has discussed this at the places quoted previously, and I have noted minor points where we differ for further consideration. Citharopsis, Pease (not Cytharopsis, A. Adams), is an absolute synonym.

Genus Seminella, Pease.-Type, Seminella varia (Pease). I consider this a well-marked group, which I will elaborate later. For the purpose of criticism I would cite as members Columbella lata, Brazier, Proc. Linn. Soc. N.S.W., vol. i, 1877, p. 232, and Zafra purpurea, H. Adams, Proc. Zool. Soc., 1873, p. 206, pl. xxiii, fig. 3.

Genus Retizafra, Hedley.-I think, in view of the complexity of these small "Columbelloids", it would be best to at once consider Retizafra as a genus. Through all the variation of Zafra no close approach to these reticulate shells is found, and as we might proceed almost directly from Zafra into Seminella, and thence to Euplica, while on the other hand we can grade into a quite smooth shell, I cannot demonstrate a subgeneric value for Retizafra.

Euplica was provided by Dall (Bull. Mus. Comp. Zool. (Harv.), vol. xviii, June, 1889, p. 187) with Columbella turturina, Duclos, as type. To this genus belongs Columbella versicolor, Sowerby, though this shell has been commonly classed in the same sub-genus as C. tyleri, Gray, which I refer to Pyrene. I will elaborate the relationships of this species later, as I have to deal completely with all the above-named species.

Genus Zafrona, nov. gen.-Introduced for Columbella isomella, Duclos. The forms at present ranged by me under this name will be reviewed later, as will most of the other species referred to previously.

This note may appear lengthy, but I have endeavoured to limit my remarks to the generic names concerned, and I will fully review the species when I later report on the collections named. Only one further point will I touch on now, and that is the family name. I maintain it should be called Pyrenidæ, not Columbellidæ, while 
I agree with Dall and Hedley that Pyrene is a distinct genus from Columbella. I have been questioned as to my argument, the only rule in this connexion reading "The name of a family is formed by adding the ending -ide... to the root of the name of its type genus". The only trpe genus of a family I can recognize is the oldest genus admitted in the family. The selection of any other would cause as much confusion as there is in recognizing the type species of a genus at present, and give rise to even more complications.

Trivia.

In these Proceedings, rol. viii, 1909, p. 288 et seq., H. O. N. Shaw gave some "Notes on the genera Cypraa and Trivia". These notes were of special value as therein was accepted the fact that the "Descr. Cat. Shells by J. E. Gray", usually quoted as of 1832 , was never published at that date, but only existed in proof.

Shaw endeavoured to trace the first publication of the new species generally credited to the above-named Catalogue. There is, and always will be, great difficulty in fixing the first user of a manuscript name, when such name has been made commonly available to all contemporary workers. Consequently I now show that most of the data, as regards generic names, provided by Shaw, must be amended, but do not suggest my own results are final. These must be regarded as simply stepping-stones, and my facts are open to further correction as soon as published.

Thus, according to Shaw, Luponia and Trivia dated from the Conchological Manual of Sowerby, 1839 ; Aricia from H. \& A. Adams, 1854 ; and Naria from Gray, 1857. I had noted Luponia occurred in Sowerby's Conch. Illus., Cypræadæ[sic], p. 12, published in Nov.-Dec. 1837, when I referred to the Penny Cyclopedia, vol. viii, and found that Broderip monographed the Cypræidæ on pp. 254-9, and that his account was based on Gray's "Descr. Cat." Broderip wrote: "Mr. Gray, whose arrangement we select, as being, in our opinion, the best which has hitherto appeared." This article was published in June, 1837, or earlier, so that the above four generic or subgeneric names date from here as ther all occur in this essay.

On p. 255 Cypraa is subdivided into sub-genera, the sub-genus Cypraa being accompanied by two illustrations, one of Cypraa childreni, Gray, with figs. $a, b$ in text, loc. (?); and the other of Cyprea adamsonii, Gray, two figures in text, from Pacific Ocean (?). On the same page the sub-genus Aricia was proposed with species Cypraa guttata, moneta, etc. On p. 256 the sub-genus Naria appears with only Cypraa irrorata, Gray, described from South Seas with two figures in text. Again, the genus Luponia is defined (p. 256) with only the species Luponia algoensis, figured and described, followed by genus Cyprcoovula, with $C$. capensis alone. Then comes the genus Trivia, which is divided into four sections:

Section a, Tivivia carnea, fig. 2 in text and described.

$\begin{array}{llll}\beta, & \text { europaa } & , & , \\ \%, & \text { pediculus } & , & , \\ \delta, & \text { pustulata } & , & ,\end{array}$


In the Proc. Zool. Soc., 1847, p. 142, Gray designated as type of his own genus Trivia, Cypraa europaa. Consequently we retain Trivia in its accepted usage. It is possible that the specialist will find it worth while to examine this article carefully, and I note that Trivia carnea may be sanguinea, but no change seems necessary in the species-names as given by Shaw. I, at present, am only concerned with Trivia, which I now quote as of Broderip, Ponny Cyclopadia, vol. viii, June, 1837 , p. 256 (ex Gray MS.).

I would add that the Natural History articles contained in the Penny Cyclopadia were reprinted under the name English Cyclopadia, edited by C. Knight, who had the articles brought up to date. In this case the article Cypræidæ appears in Natural History, vol. ii, 1854, coll. 281-9, but nothing of importance is appended in this later publication.

Lambis, Bolten, 1798.

I would just note that the type of this genus, by tautonymy, would be $L$. lambis, which appears to be a form of the shell known as Pterocera lambis, and consequently Lambis would displace Pterocera, Lamarck, which dates from 1799.

\section{Dunkeria, Carpenter.}

This name was introduced as a sub-genus of Chemnitzia by Carpenter in the Cat. Mazatlan Shells, B.M., 1857, p. 433, with the diagnosis "Chemnitzia, anfractibus tumidis, decussatis". No type was named and four species were attached, viz. D. paucilirata, subangulata, cancellata, and intermedia.

Fischer (Man. Conch., p. 790, Aug. 31, 1885) ranked Dunkeria as a sub-genus of Turbonilla, naming $D$. paucilirata as example. This is not type designation according to the International Rules, but in the Proc. Biol. Soc. Wash., vol. xvii, Feb. 5, 1904, p. 8, Dall and Bartsch definitely named as type the first species, as Fischer had selected. The Rules read, "Such designation is not subject to change," but the same authors in the U.S. Nat. Mus., Bull. 68, Dec. 13 , 1909, p. 12, gave as type D. subangulata, the explanation for their action being given on p. 120 as follows :-

" Doctor Carpenter, after diagnosing Dunkeria laminata (Ann. Mag. Nat. Hist., 1865, p. 396), writes: 'This beautiful Fenelloid species may be regarded as the type of the group of Dunkeria.' Unfortunately this species was not included in the original list, hence cannot serve as type for the group. We had selected the first species, Dunkeria paucilirata, of the four cited by Carpenter in his Mazatlan Catalogue, for the type in our Synopsis of the Genera, Subgenera, and Sections of the Family Pyramidellidæ. Since then we have seen Doctor Carpenter's material in the British Museum, and we find that Dunkeria paucilirata is a Pyrgisculus, and that the second species, Dunkeria subangulata, resembles $D$. laminata in form and sculpture, and this bears out the author's intent of typifying the group. $D$. cancellata must be removed to Pyrgisculus and D. intermedia to Evalina."

The argument here presented is not valid, and since I drew up 
this note Dr. Bartsch has kindly written me "to carefully note. . . the rules . . . and to hold to them absolutely rigidly". It is somewhat unfortunate that my first instance of the rigid application of the Rules should be in connexion with one of Dr. Bartsch's own rulings. $\mathrm{I}$, however, would remedy this matter by proposing

Bartschella, nov. gen.

with Dunkeria subangulata, Carpenter, as type.

On Dall \& Bartsch's conclusions, Dunkeria would replace Pyrgisculus, while Bartschella will come into use for the group Dunkeria, Dall and Bartsch, 1909.

A matter of dates may here be stated. In quoting Dunkeria I observed that Dall \& Bartsch wrote "Cat. Mazatlan Shells, 1856". In the Proc. U.S. Nat. Mus., vol. xlix, July 24, 1915, p. 34, Bartsch has explained this, writing: "His report, Catalogue of the Collection of Mazatlan Shells in the British Museum, was published in parts during the years 1855-1857, the part dealing with our genus appearing in 1856." This is not quite correct, so that it seems necessary to publish the facts at once in order to avoid complications later.

In the Cat. Lib. Brit. Mus. (Nat. Hist.), vol. i, 1903, p. 318, under Carpenter (P. P.), an edition published at Warrington is recorded with the dates "1855-57". This, however, is only a re-issue of the London edition with a new title-page and preface, and the dates 1855-7 are therefore wrongly given. It was published later than the London edition, and the dates only refer to the proof-sheets, not to publication. The Mazatlan Catalogue was “Printed by P. P'. Carpenter, Oberlin Press, Warrington", but was published in one item by the British Museum authorities after June, 185\%. A preface was written by John Edward'Gray, signed "April 22, 1857 ". The first sheet bears the signature "July 1855 b", the second "Aug. $1855 \mathrm{c}$ ", the third "Aug. $1855 \mathrm{~d}$ ", and so on, the last bearing "June $1857 \mathrm{yy}$ ". The signatures have been mistaken by Bartsch for dates of publication, but Carpenter, on p. 546, wrote, “The proof-sheets of this work having been submitted to several naturalists, and fresh sources of information having been obtained during its progress, the following errors have been discovered and additions made."

Elusa, A. Adams.

Elusa was proposed by A. Adams in the Ann. Mag. Nat. Hist., ser. III, vol. vii, April, 1861, p. 297, with only species E. teres. He later included in the genus his Pyramidella subulata of the Thes. Conch., vol. ii, 1855, p. 815, pl. clxxii, fig. 13 ; Proc. Zool. Soc., May 16,1855 , p. 177 , pl. xx, fig. 6. This species was erroneously given as the example by Fischer (Man. de Conch., p. 787, Aug. 31, 1885). 'This error prejudiced writers such as Hedley, Smith, and Melvill, who utilized Elusa for subulata. It escaped the notice of these writers that A. Adams had been anticipated in his selection of Elusa by Walker in the List Spec. Lepid. Insects, B.M., pt. xvi, p. 202, 1858 . 
I am publishing this note to draw attention to the fact that Dall \& Bartsch (Proc. Biol. Soc. Wash., vol. xvii, Feb. 5, 1904, p. 5) have provided as substitute for this misusage of Elusa the name Tropeas, Dall \& Bartsch, introduced for Pyramidella subulata, A. Adams.

They did not explain that Elusa was typified by E. teres, which. they considered generically distinct from the former, nor that Elusa was also invalid. In the U.S. Nat. Mus., Bull. 68, Dec. 13, 1909, pp. 28-9, ther did, however, place Elusa as an absolute synonym of Turbonilla, without, however, adding any remarks. In the meanwhile the misusage of Elusa has been continued by Melvill, Schepman, and Hedles, and it is to prevent the further perpetuation of this error that I have given this explanation. 


\section{$2 \mathrm{BHL}$ Biodiversity Heritage Library}

Iredale, Tom. 1916. "ON SOME NEW AND OLD MOLLUSCAN GENERIC NAMES." Proceedings of the Malacological Society of London 12, 27-37.

View This Item Online: https://www.biodiversitylibrary.org/item/53698

Permalink: https://www.biodiversitylibrary.org/partpdf/203163

\section{Holding Institution}

Smithsonian Libraries

\section{Sponsored by}

Smithsonian

\section{Copyright \& Reuse}

Copyright Status: Public domain. The BHL considers that this work is no longer under copyright protection.

This document was created from content at the Biodiversity Heritage Library, the world's largest open access digital library for biodiversity literature and archives. Visit BHL at https://www.biodiversitylibrary.org. 